\title{
Effect of Hybrid Binder on Properties of Geopolymer Concrete - State of Art
}

\author{
Premkumar R, Ramesh Babu Chokkalingam, PL. Meyyappan , M Shanmugasundaram \\ Ragasree A
}

\begin{abstract}
Natural pozzolans are colossal wellspring of receptive silica and alumina required for geopolymer amalgamation as an alternative binder for conventional Portland concrete. They are accessible at a relatively minimal effort and produce a low environmental impression through their basic extraction. Following audit paper condenses the mechanical and durability attributes just as the micro structural properties of common pozzolan based geopolymers and their potential as binder. The stretch out of geopolymerization increments with the expansion of curing temperature invigorating higher compressive at early ages with no huge effect on later age strength, in any case, expansion of different cementitious materials and hybrid binder improves the mechanical and durability properties of these geopolymers. This paper displays a succinct audit of different examinations that have demonstrated the use of different modern waste items in the amalgamation of geopolymers.
\end{abstract}

Keywords : Durability Properties, Geopolymer Concrete, Hybrid binder, Mechanical Properties.

\section{INTRODUCTION}

$\mathrm{I}_{\mathrm{n}}$ n the course of the most recent couple of decades, fast industrialization and urbanization is occurring the whole way across the world. This fast industrialization affects the bond utilization, which has been enormously expanding and thusly has prompted the discharge of a lot of $\mathrm{CO} 2$ into the air [1]. Creation of one ton cement lead to outflow of roughly 1 ton of $\mathrm{CO} 2$ from the response of materials and furthermore through fuel utilization for delivering concrete. One exertion to battle deficit is the advancement of exchange binder to Portland bond going for to decrease the natural effect of development, utilization of more noteworthy extent of waste pozzolan, and furthermore to improve concrete execution. In Geopolymer

Revised Manuscript Received on December 5, 2019

* Correspondence Author

Premkumar R*, School of Environmental and Construction Technology, Department of Civil Engineering, Kalasalingam Academy of Research and Education, Krishnan Koil, Tamil Nadu, India.Email: prem.ce@gmail.com

Ramesh Babu Chokkalingam, School of Environmental and Construction Technology, Department of Civil Engineering, Kalasalingam Academy of Research and Education, Krishnan Koil, Tamil Nadu, India. babussr@gmail.com

PL. Meyyappan, School of Environmental and Construction Technology, Department of Civil Engineering, Kalasalingam Academy of Research and Education, Krishnan Koil, Tamil Nadu, India, meyyappan@klu.ac.in

M Shanmugasundaram, School of Mechanical and Building Sciences, Vellore Institute of Technology, Chennai, Tamil Nadu, India, shanmugaresearch@gmail.com

Ragasree A, School of Environmental and Construction Technology, Department of Civil Engineering, Kalasalingam Academy of Research and Education, Krishnan Koil, Tamil Nadu, India, ragasree13121996@gmail.com concrete valuable solidifying materials, for example, Fly ash, Ground Granulated Blast heater slag (GGBS), and metakaolin, etc. and a portion of the siliceous materials, for example, red mud are utilized as an alternative binder to Portland cement[2].

The extraordinary highlights of the geopolymer, for example, the advancement of high early quality and better protection from compound assaults pulled in light of a legitimate concern for researchers in cement and concrete research region. Geopolymers so utilized were earth well disposed materials which did not produce ozone harming substances during the polymerization procedure [3]. Most research results showed that the coupling instrument and properties of FA-slag based GP mortars were basically influenced by both of fly powder stays to slag extent and the portion of sodium oxide (Na2O). Furthermore, the SEM and XRD assessment revealed that the hydration consequences of FA-slag based GP mortars on a very basic level include undefined soluble aluminosilicate and low crystalline calcium silicate hydrate gel. Besides drying shrinkage, better mechanical properties including the compressive quality, flexural quality and water ingestion, were obtained in FA-slag based GP mortars in connection with those of OPC mortars. To acquire a decent geopolymer concrete, the sort of activator should be acclimated to the compound contained in binder. The activator generally utilized is Sodium Hydroxide $(\mathrm{NaOH})$ low $2 \mathrm{M}$ to $18 \mathrm{M}$ and Sodium Silicate $\left(\mathrm{N}_{2} \mathrm{SiO}_{3}\right)$ at a proportion somewhere in the range of 0.4 and 2.5 but most selected mix ratio is 2.5 . The present paper audits and examines creation of geopolymer concrete, mechanical, and durability properties of normal pozzolan based geopolymer acquired with antacid arrangement as hardener or activator. Since the cements rely upon their properties at nano-auxiliary level this survey additionally targets giving better comprehension of the microstructural examination results utilized so far to clarify the nanometric attributes of geopolymer materials from regular pozzolan [4].

\section{OVERVIEW OF GEOPOLYMER CONCRETE}

\section{A. Production of geopolymer concrete}

In many researchers have clearly mentioned that geopolymer concrete can be making by Alumino-Silicate materials like fly ash, slag (GGBS), metakalin, low calcium ash, high calcium ash, rice ash, etc. In geopolymer concrete was prepare by mono binder materials or combination of any one of the alumina silicate materials. 
The reactivity of these alumino silicate sources relies upon their compound make-up, mineralogical creation, morphology, fineness and polished stage content.

The primary criteria for creating stable geopolymer are that the source materials ought to be profoundly nebulous and have adequate receptive lustrous substance, low water request and have the option to discharge aluminum effectively. In Table I show the basic activators, for example, sodium hydroxide $(\mathrm{NaOH})$, potassium hydroxide $(\mathrm{KOH})$, sodium silicate $\left(\mathrm{Na}_{2} \mathrm{SiO}_{3}\right)$ and potassium silicate $\left(\mathrm{K}_{2} \mathrm{SiO}_{3}\right)$ are utilized to initiate the reaction of alumino silicate materials. Till date, a considerable lot of the design mix constraint of geopolymer concrete (GPC) influence it's compressive strength, for example, $\mathrm{SiO}_{2} / \mathrm{Al}_{2} \mathrm{O}_{3}$, included water, temperature restoring, curing condition, concentration of $\mathrm{NaOH}$, ratio of alkaline solution and $\mathrm{Na} 2 \mathrm{O} / \mathrm{Al} 2 \mathrm{O} 3$ proportion of fly slag (FA) as shown in Table I. Yung-Chin Ding et al (2017) studied the $\mathrm{SiO}_{2} / \mathrm{Na}_{2} \mathrm{O}$ molar proportion of the salt activator assumes a significant job on the age of geopolymerization responses [5].
Pradip Nathet al (2016) presented that utilizing low calcium fly cinder with a little level of added substance, for example, ground granulated impact heater slag (GGBFS) and hydrated lime to upgrade early age properties of geopolymer concrete [9]. Ali Nazari et al(2011), Partha Sarathi Deb et al (2014) [10], B. Singh et al (2016) [11], S.M. Alamgir Kabir et al (2017) [3] reported that geopolymer enactment expands, the compressive quality of cement decreased likely due to the hard microstructure and the complexities between the stage sythesis at the total glue interface and the mass matrix. The volumetric degree of total and cover substance affected the modulus of flexibility at an animated of cement. At an early age, the test compressive quality of fly searing flotsam and jetsam/slag geopolymer cement was raised than the condition of ordinary cement concrete because of the quick geopolymerization response. It was seen that expanding activator focus in the blends brought about higher all out warmth discharge in the paste creation.

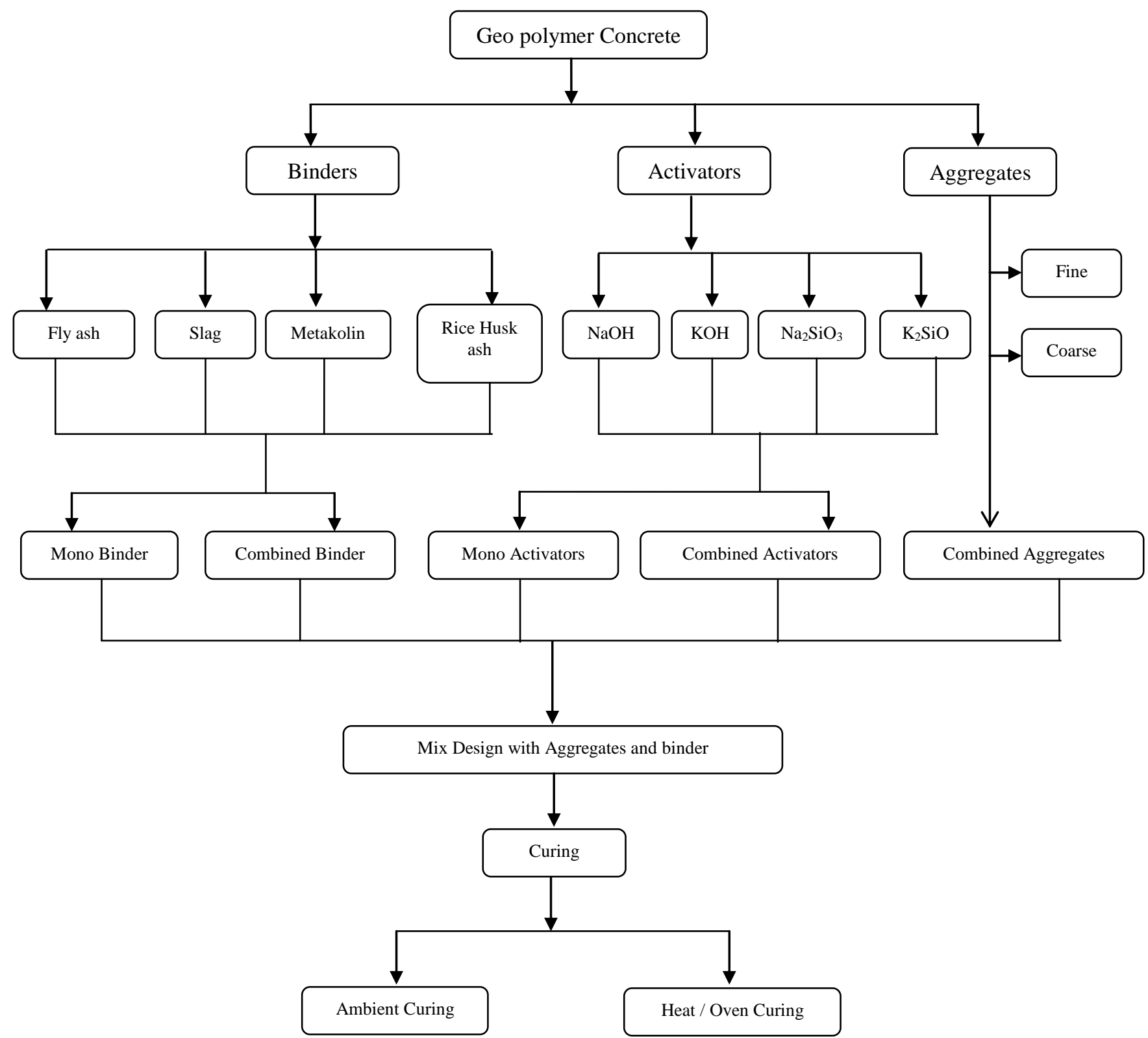

Fig. 1.Development of Geopolymer Concrete 
Table- I: Summary on Hybrid binder geopolymer concrete.

\begin{tabular}{|c|c|c|c|c|}
\hline Author Name & $\begin{array}{c}\text { Raw Material \& } \\
\text { Activator }\end{array}$ & $\begin{array}{l}\text { Alkaline Solution } \\
\text { Used }\end{array}$ & Curing Method & Remark \\
\hline SmithSongpiriyakij (2010) [12] & $\begin{array}{l}\text { Fly-Ash and Rice Husk } \\
\text { Bark Ash }\end{array}$ & $\begin{array}{l}14 \text { and } 18 \mathrm{M} \mathrm{NaOH} \\
\text { and } \mathrm{Na}_{2} \mathrm{sio}_{2}\end{array}$ & $\begin{array}{l}\text { oven curing of } \\
\text { temperature } \\
60^{\circ} \mathrm{C} \text { for } 24 \mathrm{hrs} \\
\text { and ambient } \\
\text { temperature at } \\
\quad 27^{\circ} \mathrm{C}\end{array}$ & $\begin{array}{l}\text {-optimum } \mathrm{SiO} 2 / \mathrm{A} 12 \mathrm{O} 3 \text { proportion to acquire } \\
\text { the most elevated compressive quality } \\
\text {-Fly ash was more reactive than RHBA. }\end{array}$ \\
\hline Partha Sarathi Deb (2013)[10] & GGBFS and Fly Ash & $\begin{array}{l}\text { 14M NaoH and } \\
\mathrm{Na}_{z} \text { sio }_{2}\end{array}$ & $\begin{array}{l}\text { Ambient } \\
\text { temperature }\end{array}$ & $\begin{array}{l}\text {-Compressive strength cement expanded with } \\
\text { the expansion of slag content }\end{array}$ \\
\hline N.K. Lee (2013) [7] & $\begin{array}{l}\text { Class F-type Fly Ash and } \\
\text { Slag }\end{array}$ & $\begin{array}{l}4,6,8 \mathrm{M} \mathrm{NaOH} \text { and } \\
\mathrm{Na}_{z} \mathrm{sio}_{2} \text { of ratio } \\
0.5,1.0,1.5\end{array}$ & $\begin{array}{l}\text { Ambient } \\
\text { temperature }\end{array}$ & $\begin{array}{l}\text { - proper trade proportion of the slag for the fly } \\
\text { ash remains by weight in the antacid } \\
\text { initiated fly cinder/slag blend is } 15-20 \%\end{array}$ \\
\hline J.M. Mejía (2013)[18] & $\begin{array}{l}\text { Rice Husk Ash, Glass } \\
\text { Waste }\end{array}$ & $\mathrm{NaOH}$ and $\mathrm{Na}_{2} \mathrm{Sio}_{2}$ & $\begin{array}{l}\text { oven curing of } \\
\text { temperature } 80^{\circ} \mathrm{c} \\
\text { for } 24 \mathrm{hrs}\end{array}$ & $\begin{array}{l}\text {-only the } 100 \% \text { FA required thermal curing } \\
\text {-alkali-activated materials can be achieved } \\
\text { from FA, GBFS or hybrid FA/GBFS }\end{array}$ \\
\hline N.Marjanović (2014)[8] & $\begin{array}{l}\text { Fly-Ash and Blast } \\
\text { Furance Slag }\end{array}$ & $\mathrm{NaOH}$ and $\mathrm{Na}_{2} \mathrm{sio}_{2}$ & $\begin{array}{l}\text { Oven curing of } \\
\text { temperature } 95^{\circ} \mathrm{c} \\
\text { for } 24 \mathrm{hrs}\end{array}$ & $\begin{array}{l}\text {-High centralization of the activator } \\
(10 \% \mathrm{Na} 2 \mathrm{O}) \text { added to better quality of } \\
\text { mortars with transcendent substance of FA } \\
\text { in the mix }\end{array}$ \\
\hline Azizul Islam (2014) [15] & $\begin{array}{l}\text { GGBFS, Fly-Ash and } \\
\text { Palm Oil Fuel Ash }\end{array}$ & $\begin{array}{l}12 \mathrm{M} \mathrm{NaOH} \text { and } \\
\mathrm{Na}_{2} \mathrm{SiO}_{2}\end{array}$ & $\begin{array}{l}\text { Oven curing of } \\
\text { temperature } \\
65^{\circ} \mathrm{C} \text { and kept at } \\
\text { ambient } \\
\text { temperature of } \\
27^{\circ} \mathrm{C}\end{array}$ & $\begin{array}{l}\text {-highest compressive strength. } \\
\text { - desired workability, dense mix } \\
\text {-development of sustainable construction } \\
\text { material. }\end{array}$ \\
\hline Robert J. Thomas (2015) [30] & GGBFS, Class F Fly-Ash & $\mathrm{NaOH}$ and $\mathrm{Na}_{2} \mathrm{SiO}_{2}$ & $\begin{array}{l}\text { two curing were } \\
\text { conducted are } \\
\text { oven } \\
\text { temperature } \\
50^{\circ} \mathrm{C} \text { for } 48 \mathrm{hrs} \\
\text { and ambient } \\
\text { temperature } \\
22^{0} \mathrm{C}\end{array}$ & $\begin{array}{l}\text {-low strength for ambient cured Fly-Ash } \\
\text { activated concrete } \\
\text {-salt actuated GGBFS solid shows profoundly } \\
\text { fragile conduct set apart by close to } \\
\text { consummate straight flexibility pursued by } \\
\text { unexpected and absolute disappointment. }\end{array}$ \\
\hline Pradip Nath (2016) [9] & $\begin{array}{l}\text { Low calcium Fly Ash, } \\
G G B S, O P C\end{array}$ & $\begin{array}{l}14 \mathrm{M} \mathrm{NaOH} \text { and } \\
\mathrm{Na}_{z} \mathrm{sio}_{z} \text { of ratio } \\
1: 2.5\end{array}$ & $\begin{array}{l}\text { Ambient } \\
\text { temperature }\end{array}$ & $\begin{array}{l}\text {-Modulus of elasticity increased } \\
\text {-Relieving in ordinary room temperature } \\
\text { delivered cement of comparable modulus of } \\
\text { flexibility to that of the GPC restored in } \\
\text { raised temperature }\end{array}$ \\
\hline B. Singh (2016) [11] & Fly-Ash and GGBFS & $\begin{array}{l}10 \text { to } 16 \mathrm{M} \mathrm{NaoH} \\
\text { and } \mathrm{Na}_{2} \text { sio }_{2} \text { of } \\
\text { ratio } 1: 2.5\end{array}$ & $\begin{array}{l}\text { Ambient } \\
\text { Temperature }\end{array}$ & $\begin{array}{l}\text {-Increase the impact resistance of the } \\
\text { specimen } \\
\text { - Good bonding between the paste and } \\
\text { aggregate. } \\
\text {-optimum activator concentration leading to } \\
\text { increase the compressive strength at room } \\
\text { temperature }\end{array}$ \\
\hline Ghasan F. Huseien (2016)[14] & $\begin{array}{l}\text { Metakaolin and GGBFS } \\
\text { Sika Visco Crete- } 3430\end{array}$ & $\begin{array}{l}10,14,16,18 \mathrm{M} \\
\mathrm{NaoH} \text { and } \mathrm{Na}_{2} \text { sio }_{2}\end{array}$ & $\begin{array}{l}\text { Ambient } \\
\text { Temperature }\end{array}$ & $\begin{array}{l}\text {-calcium and silicate contents was increased } \\
\text { the density was reduced } \\
\text { - Compare with OPC higher mechanical } \\
\text { properties. } \\
\text {-alternative potential repair material }\end{array}$ \\
\hline Hervé K. Tchakouté (2016) [16] & $\begin{array}{l}\text { Rice husk Ash, } \\
\text { matakaolin, Waste Glass } \\
\text { Powder }\end{array}$ & $\mathrm{NaOH}$ and $\mathrm{Na}_{2}$ sio $_{2}$ & $\begin{array}{l}\text { Ambient } \\
\text { Temperature }\end{array}$ & $\begin{array}{l}\text {-sodium waterglass from waste glass and rice } \\
\text { husk cinder are reasonable option antacid } \\
\text { answers for the generation of } \\
\text { metakaolin-based geopolymer covers } \\
\text {-The quality of geopolymer fasteners } \\
\text { expanded with the restoring time. }\end{array}$ \\
\hline
\end{tabular}




$\begin{array}{ll}\text { chee Ban cheah (2017) [1] } & \begin{array}{l}\text { GGBFS, Pulverized } \\ \text { FlyAsh and high calcium } \\ \text { wood Ash }\end{array} \\ \text { S.M.Alamgir Kabir (2017)[3] } & \begin{array}{l}\text { GGBFS, Metakaolin, } \\ \text { Palm oil Fly Ash and oil }\end{array} \\ & \text { Palm Shell, Palm oil } \\ \text { Clinker }\end{array}$

A. Karthik (2017) [6]

Yung-Chin Ding (2017) [5]
GGBFS and Fly-Ash

Coal Fly-Ash and Blast Furance Slag
$12 \mathrm{M} \mathrm{NaoH}$ and $\mathrm{Na}_{z} \mathrm{SiO}_{2}$ of ratio $0.1: 1.2$

$14 \mathrm{M} \mathrm{NaoH}$ and $\mathrm{Na}_{2} \mathrm{SiO}_{2}$ of ratio $1: 2.5$

Ambient temperature

oven curing of $65^{\circ}$ for $24 \mathrm{hrs}$ and kept at ambient temperature

$8 \mathrm{M} \mathrm{NaoH}$ and Ambient $\mathrm{Na}_{2} \mathrm{SiO}_{2}$ of ratio temperature of $1: 2.5$

$\mathrm{NaOH}$ and $\mathrm{Na}_{2} \mathrm{SiO}_{2}$

Ambient temperature
Abd Allah R. Abd

EL-moatey (2017) [17]

Jingping Qiu (2019)[21]

Bavita Bhardwaj (2019) [20]

Wei-Hao Lee (2019)[24]

Nana Wen (2019) [4]

Jianhe Xie (2019) [19]
GGBFS, Metakaolin

Fly-Ash, GGBFS

Fly-Ash, GGBFS,OPC

GGBFS, Fly-Ash

Rice Husk Ash, MRA,300S

GGBFS, Fly-Ash, OPC
$\mathrm{NaOH}$ and $\mathrm{Na}_{2} \mathrm{SiO}_{2} \quad$ Ambient

Temperature

$8 \mathrm{M} \mathrm{NaoH}$ and $\mathrm{Na}_{2} \mathrm{SiO}_{2}$ oven curing of temperature $40^{\circ}$ for $24 \mathrm{hrs}$ and Ambient temperature

14M NaoH and Ambient $\mathrm{Na}_{z} \mathrm{SiO}_{2} \quad$ Temperature

$\begin{array}{ll}2 \mathrm{M}, 3 \mathrm{M}, 4 \mathrm{M}, 5 \mathrm{M}, 6 & \text { Ambient } \\ \mathrm{M} \mathrm{NaOH} \text { and } & \text { Temperature } \\ \mathrm{Na}_{2} \mathrm{SiO}_{2} & \end{array}$

8,10,14,18M NaoH Ambient and $\mathrm{Na}_{2} \mathrm{SiO}_{2} \quad$ temperature

$\mathrm{NaOH}$ and $\mathrm{Na}_{2} \mathrm{SiO}_{3}$ oven curing of ratio of $1: 2.5$ temperature $80^{\circ} \mathrm{C}$ for $24 \mathrm{hrs}$ and speciemens were kept at ambient temperature -compact and denser microstructure

-development on the hybrid geopolymer mixes.

-improves the compressive toughness

-improve the crack growth resistance of structures

-dense geopolymer binding gel leading to homogeneity

-bio-additives added geopolymer specimen -enhance durability

-The $\mathrm{SiO} 2 / \mathrm{Na} 2 \mathrm{O}$ molar proportion of the soluble base activator assumes a significant job on the quality of geopolymer glue.

$-120 \%$ fixing rate can be accomplished.

-slag/fly fiery remains based geopolymer glue has generally excellent building improvement later on.very good engineering development in the future.

-Geopolymer structure gets increasingly steady structure in nearness of MK.

-Increase the compressive strength of geopolymer concrete

-compressive strength decreased in ambient curing condition

-Alkali activated slag concrete mixes improve the compressive strength all replacement level of binder.

higher $\mathrm{NaOH}$ fixations can bring about higher disintegration of $\mathrm{Al}$ and $\mathrm{Si}$ particles and the development of alumino-silicate prompting an expansion in quality

-Reduce the quantity of RHA increase compressive strength

$-\mathrm{NaOH}$ concentration, most important to a higher compressive strength.

-Growing the $\mathrm{NaOH}$ concentration decrease the workability

Table II: Effect of different oxides in geopolymer concrete

\begin{tabular}{|c|c|c|c|c|c|c|c|c|c|}
\hline S.No & Element as oxide & $\mathrm{SiO}_{2}$ & $\mathrm{Al}_{2} \mathrm{O}_{3}$ & $\mathrm{Fe}_{2} \mathrm{O}_{3}$ & Mgo & $\mathrm{CaO}$ & $\mathrm{K}_{2} \mathrm{O}$ & $\mathrm{Na}_{2} \mathrm{O}$ & Author Name \\
\hline \multirow[b]{2}{*}{1} & Granulated Blast Furance Slag(GGBS) & 32.84 & 13.27 & $0.2 \varepsilon$ & 6.08 & 40.8 & 0.36 & \multirow{2}{*}{\multicolumn{2}{|c|}{ chee Ban cheah [1] }} \\
\hline & Pulverized Fuel Ash(PFA) & 43.22 & 17.61 & 13.73 & 5.94 & 11.28 & 1.31 & & \\
\hline \multirow[b]{2}{*}{2} & Fly Ash & 53.71 & 27.20 & 11.17 & - & 1.90 & 0.54 & \multirow{2}{*}{\multicolumn{2}{|c|}{$\begin{array}{c}\text { Partha Sarathi } \\
\text { Deb [2] }\end{array}$}} \\
\hline & GGBS & 29.96 & 12.25 & 0.52 & - & 45.45 & 0.38 & & \\
\hline \multirow[b]{2}{*}{3} & Metakaolin & 52.68 & 42.42 & 2.01 & 0.12 & 0.04 & 0.34 & 0.07 & $\begin{array}{c}\text { S.M.Alamgir Kabir } \\
{[3]}\end{array}$ \\
\hline & Palm Oil Fly Ash & 63.41 & 5.55 & $4.1 \mathrm{c}$ & 3.74 & 4.34 & 6.33 & 0.16 & \\
\hline
\end{tabular}




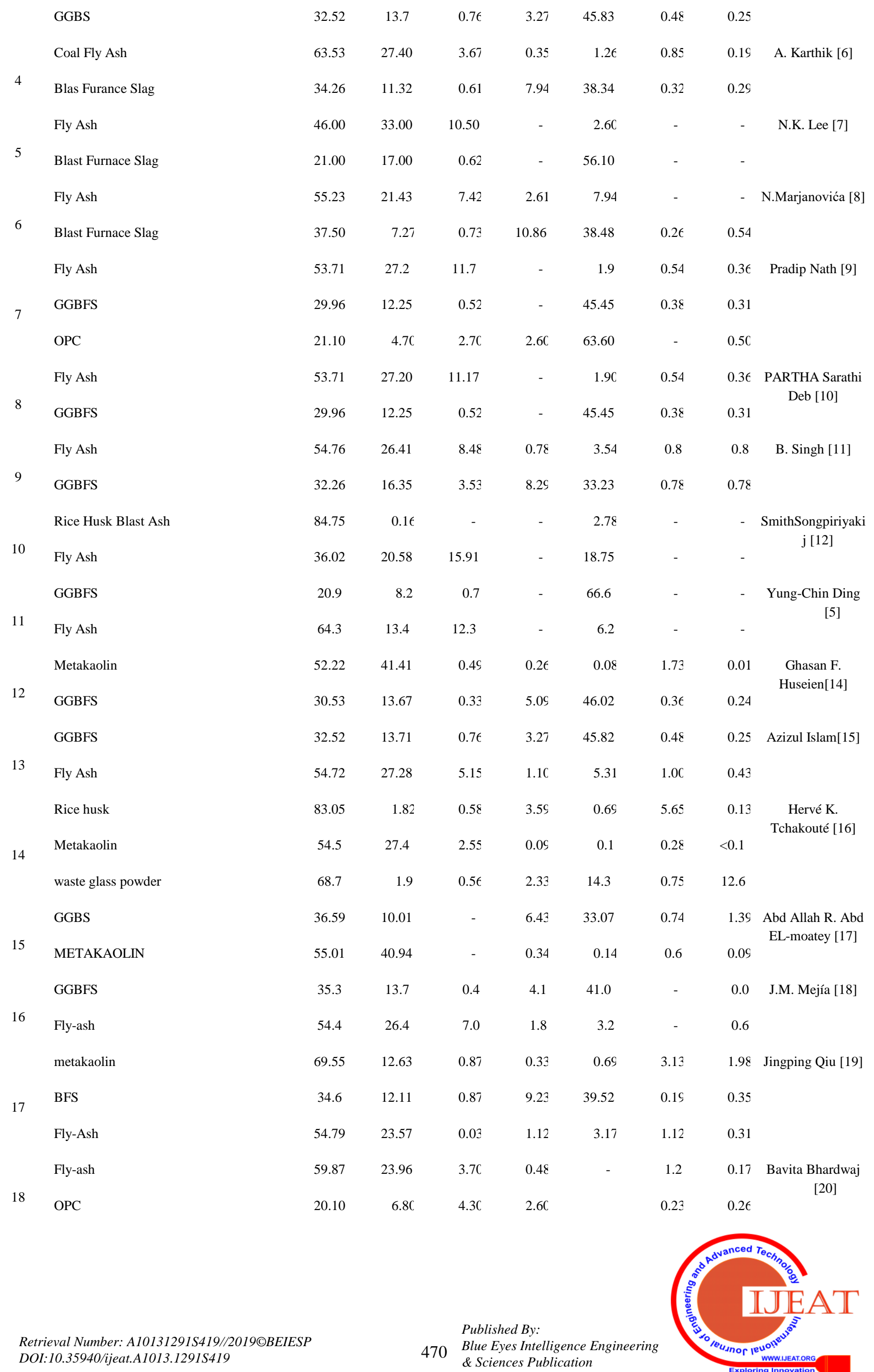




\begin{tabular}{|c|c|c|c|c|c|c|c|c|c|}
\hline & GGBFS & 33.06 & 22.29 & 0.9 & 7.61 & 35.37 & - & - & \multirow[b]{2}{*}{ Aissa Bouaissi [21] } \\
\hline \multirow{3}{*}{19} & Class F Fly-Ash & 55.7 & 27.08 & 7.27 & - & $4.1 \mathrm{C}$ & 1.55 & - & \\
\hline & GGBFS & 28.2 & 9.73 & 0.99 & 2.9 & 52.69 & 1.22 & - & \multirow{4}{*}{ Wei-Hao Lee [24] } \\
\hline & HMNS & 43.22 & 4.35 & 10.34 & 26.15 & 3.45 & 0.18 & 0.23 & \\
\hline \multirow[b]{2}{*}{20} & GGBFS & 26.6 & 11.4 & 0.4 & - & 58.6 & 0.6 & - & \\
\hline & Fly-ash & 69.3 & 13.3 & 7.9 & - & 5.1 & 2.2 & - & \\
\hline \multirow{3}{*}{21} & Fly-Ash & 66.56 & 22.47 & 3.54 & 0.65 & 1.64 & 1.75 & 0.58 & \multirow[t]{3}{*}{$\begin{array}{c}\text { Amin Noushini } \\
{[25]}\end{array}$} \\
\hline & kaolite & 45.14 & 33.32 & 11.99 & 1.37 & 4.13 & 0.13 & 0.07 & \\
\hline & GGBFS & 31.52 & 12.22 & 1.14 & 4.62 & 44.53 & 0.33 & 0.21 & \\
\hline \multirow[b]{2}{*}{22} & Slag & 35.54 & 13.65 & $0.3 \mathrm{c}$ & 4.11 & 41.0 & - & 0.01 & \multirow[t]{2}{*}{ F. Puertas [29] } \\
\hline & Glass Waste & 70.71 & 2.05 & 0.52 & 1.17 & 11.75 & 1.08 & 11.71 & \\
\hline \multirow{2}{*}{23} & GGBFS & 36.0 & 10.5 & 0.7 & 7.9 & 39.8 & 0.2 & 0.3 & \multirow{2}{*}{$\begin{array}{c}\text { Robert J. Thomas } \\
{[30]}\end{array}$} \\
\hline & Class C Fly-Ash & 37.7 & 20.0 & 5.6 & 4.3 & 23.4 & 0.6 & 1.7 & \\
\hline \multirow{2}{*}{24} & Fly-Ash & 54.44 & 27.51 & $6.3 \varepsilon$ & 1.51 & 2.72 & 3.13 & 1.51 & \multirow{2}{*}{$\begin{array}{c}\text { M. Torres-Carrasco } \\
{[31]}\end{array}$} \\
\hline & Glass Waste & 70.71 & 2.05 & 0.52 & 1.17 & 11.75 & 1.08 & 11.71 & \\
\hline \multirow[b]{2}{*}{25} & Ricehusk Ash & 89.02 & 0.77 & 0.55 & $0.4 \mathrm{C}$ & 2.45 & 3.94 & - & \multirow[t]{2}{*}{ Nana Wen [4] } \\
\hline & MRA & 81.62 & 5.85 & 4.9 & $0.2 \epsilon$ & 0.74 & 3.0 & - & \\
\hline \multirow{3}{*}{26} & GGBS & 35.52 & 13.60 & 0.61 & $9.5 \varepsilon$ & 35.05 & - & & \multirow[t]{3}{*}{ Jianhe Xie [27] } \\
\hline & Fly-Ash & 51.49 & 24.36 & $5.4 \mathrm{C}$ & 1.2 & 9.8 & - & - & \\
\hline & OPC & $20-24$ & $4-7$ & $5-6$ & 0.9 & $62-67$ & - & - & \\
\hline
\end{tabular}

\section{B. Effect of different oxides in geopolymer concrete}

Even more basically, the starting spread material accepts a noteworthy job in the geopolymeric reaction and impacts the mechanical properties of the last set thing. In Table II show the source material fundamentally incorporates $\mathrm{Fe}_{2} \mathrm{O}_{3}, \mathrm{Na}_{2} \mathrm{O}$, $\mathrm{K}_{2} \mathrm{O}, \mathrm{SiO}_{2}, \mathrm{Al}_{2} \mathrm{O}_{3}$ and $\mathrm{CaO}$. Of this, $90 \%$ is contributed by $\mathrm{SiO}_{2}, \mathrm{CaO}, \mathrm{Al}_{2} \mathrm{O}_{3}$ and $\mathrm{Fe}_{2} \mathrm{O}_{3}$, with various oxides proximity being commonly low. In this manner, the activity of these oxides is apparently of critical impact on the mechanical quality of the geopolymer concrete. The geopolymerization reaction basically incorporates the substance reaction between the broke down sorts of silicates and aluminates inside seeing significantly solvent activator arrangement. Various researchers were found that the oxide structure of the source material has basic effect on the compressive quality of the geopolymer concrete. Thusly, unprecedented thought is required while picking the source material to be utilized for making geopolymer concrete and is crucial to decide the perfect level of each oxide part to get high compressive quality. Since, $\mathrm{SiO}_{2}$ and $\mathrm{Al}_{2} \mathrm{O}_{3}$ are the two significant oxides which direct the geopolymeric mastermind improvement and in this way a conclusive compressive quality, it is basic to know their typical range in the source material.

\section{Mechanical Properties}

Research investigation are obviously characteristic that the waste released from the wood biomass power plant, steel blast furnace and coal power plant can be utilized in blend within the sight of antacid activators to deliver a helpful cover stage for the concrete industry[1]. The general pattern saw from the outcomes got that the incorporation of fly ash up to $80 \%$ substitution level significantly affected expanding the compressive quality of hybrid geopolymer mortar. Compressive quality of geopolymer cement expanded with the expansion of slag content and expanded by the consideration of GGBFS, OPC or $\mathrm{CH}$ with fly fiery debris geopolymer impelled with a silicate-based plan showed a more homogeneous microstructure than that ordered with a $\mathrm{NaOH}$-based course of action, which may improve the compressive quality [10]. The development in the water glass substance came about not in an addition in the compressive quality. It was seen that geopolymer bond reliant on fly ash, slag composite mix with a perfect activator obsession made needed setting and hardening at room temperature. The compressive quality, elastic modulus and impact quality extended and the Poisson's extent reduced with growing 
activator fixation [3].

The $\mathrm{SiO}_{2} / \mathrm{Na}_{2} \mathrm{O}$ molar extents of the dissolvable base activator expect a critical activity on the nature of geopolymer concrete. Overview was moreover shown that the reactivity of the source materials just as the idea of the cross section added to the improvement of compressive nature of the geopolymer [12]. The development of extra water and naphthalene based superplasticiser improves the usefulness of the fresh geopolymer concrete; be that as it may, option of additional water with diminished antacid arrangement diminished the compressive quality of geopolymer concrete. All these test outcomes could be credited to stable cross-associated polymer structures, improved homogeneity, progressively mentioned and thick geopolymer limiting gel, filling of micropores and refinement of the pore structure in bio-included substances included geopolymer model. Sodium water glasses from waste glass and rice husk red hot remains are sensible alternative stomach settling agent answers for the formation of metakaolin-based geopolymer clasp and could replace sodium silicate game plan got from mineral sources. The utilization of locally accessible waste materials, for example, GGBS, POFA, FA and M-sand could be utilized for advancement of economical development material. The accomplishment of high bond quality of such GPMs demonstrated their capacity as an elective potential fix material. By contrasting and Portland concrete, it tends to be demonstrated that the hybrid based geopolymer glue has generally excellent potential for further building advancement later on.

\section{Durability Properties}

Prior examiners have contemplated that the show of GPC to the extent toughness is better than that of OPC concrete. Regardless, the toughness of these materials needs more assessment to see well the lead of geopolymer concrete under compelling circumstances. Various cements require various degrees of strength, contingent upon the presentation condition and wanted properties. The capacity to keep going long, without crumbling significantly is durability. Solid oppose the enduring, concoction hostility and scraped spot while holding their ideal designing properties. Everything being proportionate, higher temperature relieving favored the decrease of shrinkage because of drying up, which can profit the material's sturdiness by constraining the danger of crack. Geopolymers are as often as possible discovered, joined by lower shrinkage. The principle response result of geopolymerization comprises of an increasingly steady cross-connected aluminosilicate structure with a lower calcium content that is less defenseless to corrosive assault contrasted with ordinary cement and hydration items. Geopolymer concrete in this manner, has predominant strength in corrosive situations and could be used as a potential elective structure material that could perform superior to PC and HAC in exceptionally forceful corrosive conditions. The sorptivity normal for GPC expanded with the age of the concrete, though the sorptivity of OPC cement diminished with age. This proposes the pore structure of the open air uncovered GPC surface changes with age.

\section{CONCLUSION}

- The present work audits and abridges the fundamental components which have significant impact on the properties of geopolymers got from different modern side-effects. With reference to the present assemblage of learning in geopolymer innovation, thorough measure of study has been performed to cover the different parts of built up geopolymers, for example, FA and GGBS based geopolymers.

- Because of the nonappearance of some standard plan determinations of geopolymers, regardless of having tantamount or shockingly better quality and strength attributes, it can't supplant the typical OPC concrete from the field applications.

- Factors like fineness of sources material, measure of salt activators, relieving strategies, restoring temperature, and soon have huge impact on properties of geopolymers.

- The greater part of the calcium-based admixtures are found to improve properties of geopolymers at ordinary room temperature which widen the extent of usage of geopolymer concrete when all is said in done development applications notwithstanding the precast business

- Comprehensively, hybrid binder can be utilized to quicken the geopolymerization response as an alternative method to heat curing.

A fitting code of training for geopolymers and their items should be detailed dependent on research information and field information for mass adjustment by the clients. It is felt that the across the board take-up of geopolymer innovation is impeded by various components, specifically issues to do with an absence of long term durability information. In this generally new research field, there are additionally troubles in consistence with administrative standard, explicitly that characterizing substance organization in concrete. At the point when at least two source materials are utilized in making geopolymer solid, this regular scope of the oxides is helpful in choosing the proportion of the source materials to be utilized in the blend. Likewise, it helps in picking the correct material, when there is accessibility of a lot of various waste materials.

\section{REFERENCES}

1. Chee Ban Cheah, Muhammad Hasnolhadi Samsudin, Mahyuddin Ramli, Wei Ken Part, Leng Ee Tan, "The use of high calcium wood ash in the preparation of Ground Granulated Blast Furnace Slag and Pulverized Fly Ash geopolymers: A complete microstructural and mechanical characterization" Journal of Cleaner Production 2017, available from: doi: 10.1016/j.jclepro.2017.04.026.

2. Deb, P.S., Nath, P., Sarker, P.K., "The effects of ground granulated blast-furnace slag blending with fly ash and activator content on the workability and strength properties of geopolymer concrete cured at ambient temperature", Materials and Design (2014), available from: doi:http://dx.doi.org/10.1016/j.matdes.2014.05.001

3. S.M. Alamgir Kabir, U. Johnson Alengaram*, Mohd Zamin Jumaat, Sumiani Yusoff, Afia Sharmin, Iftekhair Ibnul Bashar, "Performance evaluation and some durability characteristics of environmental friendly palm oil clinker based geopolymer concrete" Journal of Cleaner Production vol. 161 (2017), available from: http://dx.doi.org/10.1016/j.jclepro.2017.05.002.

4. Wen N, Zhao Y, Yu Z, Liu M, "A sludge and modified rice husk ash-based geopolymer: synthesis and characterization analysis", Journal of Cleaner Production (2019), available from: doi https://doi.org/10.1016/j.jclepro.2019.04.045

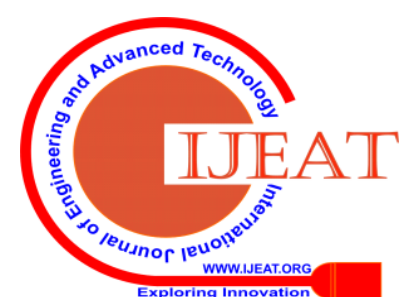


5. Yung-Chin Ding, Ta-Wui Cheng, Yu-Sheng Dai "Application of geopolymer paste for concrete repair", International Federation for Structural Concrete, (2017), available from: DOI 10.1002/suco.201600161

6. Karthik, K. Sudalaimani and C.T. Vijayakumar, "Durability study on Coal Fly Ash-Blast Furnace Slag geopolymer concretes with Bio additives", Ceramics International, available from: http://dx.doi.org/10.1016/j.ceramint.2017.06.042.

7. N.K. Lee, H.K. Lee, "Setting and mechanical properties of alkali-activated fly ash/slag concrete manufactured at room temperature" Construction and Building Materials vol.47 $\begin{array}{lll}\text { PP.1201-1209 (2013), } & \text { available } & \text { from: }\end{array}$ http://dx.doi.org/10.1016/j.conbuildmat.2013.05.107.

8. N. Marjanović,n, M.Komljenović, Z.Baščarević, V.Nikolić, R.Petrović, "Physical-mechanical andmicrostructuralpropertiesofalkali-activated fly ash-blast furnaceslagblends" Ceramics International2014, available from: http://dx.doi.org/10.1016/j.ceramint.2014.09.075.

9. Pradip Nath, Prabir Kumar Sarker, "Flexural strength and elastic modulus of ambient-cured blended low-calcium fly ash geopolymer concrete", Construction and Building Materials 2016, available from: http://dx.doi.org/10.1016/j.conbuildmat.2016.11.034.

10. PARTHA Sarathi Deb, a, PRADIP Nath, b and PRABIR Kumar Sarke, "Strength and Permeation Properties of Slag Blended Fly Ash Based Geopolymer Concrete" Advanced Materials Research Vol 651 PP. 168-173 2013, available from: doi:10.4028/www.scientific.net/AMR.651.168.

11. B. Singh, M.R. Rahman, R. Paswan, S.K. Bhattacharyya, "Effect of activator concentration on the strength, ITZ and drying shrinkage of fly ash/slag geopolymer concrete" Construction and Building Materials vol. 118 (2016)

171-179 http://dx.doi.org/10.1016/j.conbuildmat.2016.05.008.

12. Smith Songpiriyakij, Teinsak Kubprasit, Chai Jaturapitakkul, Prinya Chindaprasirt, "Compressive strength and degree of reaction of biomass- and fly ash-based geopolymer", Construction and Building Materials 24 (2010) 236-240, doi:10.1016/j.conbuildmat.2009.09.002.

13. Cheah Chee Ban, Part Wei Ken, Mahyuddin Ramli, "Mechanical and Durability Performance of novel Self-activating Geopolymer Mortar", Procedia Engineering vol.171 PP.564-571 (2017), available from: doi: 10.1016/j.proeng.2017.01.374.

14. Ghasan F. Huseien a, Jahangir Mirza a, Mohammad Ismail a, S.K. Ghoshal C, Mohd Azreen Mohd Ariffin, "Effect of metakaolin replaced granulated blast furnace slag on fresh and early strength properties of geopolymer mortar", Ain Shams Engineering Journal 2016, available from: http://dx.doi.org/10.1016/j.asej.2016.11.011.

15. Azizul Islam, U. Johnson Alengaram, Mohd Zamin Jumaat, Iftekhair Ibnul Bashar, "The development of compressive strength of ground granulated blast furnace slag-palm oil fuel ash-fly ash based geopolymer mortar", Materials and Design vol.56 PP.833-841 (2014), available from: http://dx.doi.org/10.1016/j.matdes.2013.11.080.

16. Hervé K. Tchakouté a, Claus H. Rüscher, Sakeo Kong, Elie Kamseu C, Cristina Leonelli, "Geopolymer binders from metakaolin using sodium waterglass from waste glass and rice husk ash as alternative activators: A comparative study", Construction and Building Materials vol.114 PP.276-289 (2016), available from: http://dx.doi.org/10.1016/j.conbuildmat.2016.03.184.

17. Abd Allah R. Abd EL-moatey, Ahmed S. Faried, Waleed H. Soufi, Magdy A. Abd El-Aziz. "Improve the Formation of Geopolymer Concrete Mixed with Seawater and Without Curing". American Journal of Civil Engineering. Vol. 5, No. 6, 2017, pp. 344-351, available from:doi: 10.11648/j.ajce.20170506.15.

18. J.M. Mejía, R. Mejía de Gutiérrez, F. Puertas, "Rice husk ash as a source of silica in alkali-activated fly ash and granulated blast furnace slag systems", Materiales de Construcción Vol. 63, 311, PP.361-375, available from:doi: 10.3989/mc.2013.04712.

19. Jingping Qiu, Yingliang Zhao , Jun Xing, and Xiaogang Sun, "Fly Ash/Blast Furnace Slag-Based Geopolymer as a Potential Binder for Mine Backfilling: Effect of Binder Type and Activator Concentration", Advances in Materials Science and Engineering 2019, available from:https://doi.org/10.1155/2019/2028109.

20. Bavita Bhardwaj, Pardeep Kumar, "Comparative study of geopolymer and alkali activated slag concrete comprising waste foundry sand", Construction and Building Materials vol.209 PP.555-565 (2019), available from: https://doi.org/10.1016/j.conbuildmat.2019.03.107.

21. Aissa Bouaissi a, Long-yuan Li a, Mohd Mustafa Al Bakri Abdullah b, Quoc-Bao Bui, "Mechanical properties and microstructure analysis of FA-GGBS-HMNS based geopolymer concrete", Construction and
Building Materials vol.210 PP.198-209 (2019), available from:https://doi.org/10.1016/j.conbuildmat.2019.03.202.

22. K.Parthiban, K.Saravanarajamohan, S.Shobana, A.Anchal Bhaskar, "Effect of Replacement of Slag on the Mechanical Properties of Flyash Based Geopolymer Concrete", International Journal of Engineering and Technology Vol 52013.

23. Kamaldeep Kaur, Jaspal Singh, Manpreet Kaur, "Compressive strength of rice husk ash based geopolymer: The effect of alkaline activator", Construction and Building Materials vol.169 PP.188-192 (2018), available from: https://doi.org/10.1016/j.conbuildmat.2018.02.200.

24. Wei-Hao Lee, Jhi-Hao Wang, Yung-Chin Ding, Ta-Wui Cheng, "A study on the characteristics and microstructures of GGBS/FA based geopolymer paste and concrete", Construction and Building Materials vol.211 PP.807-813 (2019), available from: https://doi.org/10.1016/j.conbuildmat.2019.03.291.

25. Noushini, F. Aslani, A. Castel, R.I. Gilbert, B. Uy, S. Foster, "Compressive stress-strain model for low-calcium fly ash-based geopolymer and heat-cured Portland cement concrete",Cement and Concrete Composites (2016), available from:doi: 10.1016/j.cemconcomp.2016.07.004.

26. Ernesto J. Guades Ph.D., "Experimental investigation of the compressive and tensile strengths of geopolymer mortar: The effect of sand/fly ash (S/FA) ratio", Construction and Building Materials vol.127 PP.484-493 (2016), available from: http://dx.doi.org/10.1016/j.conbuildmat.2016.10.030.

27. Xie J, Wang J, Rao R, Wang C, Fang C, "Effects of combined usage of GGBS and fly ash on workability and mechanical properties of alkali activated geopolymer concrete with recycled aggregate", Composites $\begin{array}{llll}\text { Part } & B & \text { (2018), available from: }\end{array}$ https://doi.org/10.1016/j.compositesb.2018.11.067

28. Parveen, Dhirendra Singhal, M. Talha Junaid, Bharat Bhushan Jindal, Ankur Mehta, "Mechanical and microstructural properties of fly ash based geopolymer concrete incorporating alccofine at ambient curing", Construction and Building Materials vol.180 PP.298-307 (2018), available from: https://doi.org/10.1016/j.conbuildmat.2018.05.286.

29. F. Puertas , M. Torres-Carrasco, "Use of glass waste as an activator in the preparation of alkali-activated slag. Mechanical strength and paste characterisation", Cement and Concrete Research vol.57 PP.95-104 (2014), available http://dx.doi.org/10.1016/j.cemconres.2013.12.005.

30. Robert J. Thomas, Sulapha Peethamparan, "Alkali-activated concrete: Engineering properties and stress-strain behavior", Construction and Building Materials vol.93 PP.49-56 (2015), available from: http://dx.doi.org/10.1016/j.conbuildmat.2015.04.039.

31. Torres-Carrasco M, Puertas F, "Waste glass in the geopolymer preparation. Mechanical and microstructural characterization", Journal of Cleaner Production (2015), available from: doi: 10.1016/j.jclepro.2014.11.074.

\section{AUTHORS PROFILE}

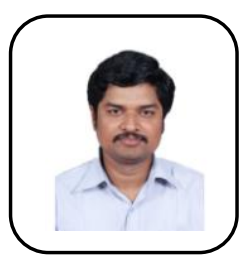

R.Premkumar had completed B.E degree in Civi Engineering and M.E degree in Structural Engineering from Anna University, Chennai, Tamil Nadu in 2008 and 2012 respectively. He is currently working as Assistant Professor in the department of Civil Engineering at Kalasalingam Academy of Research and Education. He has 2 year of industrial experience and 7 years experience in academics and consultancy. His current research interests are Geopolymer Concrete and Earthquake resistance structures.

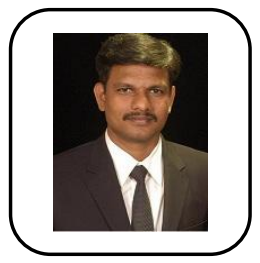

Ramesh Babu Chokkalingam completed his $\mathrm{Ph} . \mathrm{D}$. from IIT Chennai. He has more than ten years of experience in teaching and research. His areas of research includes pervious concrete, geopolymer concrete, and high volume flyash concrete. 


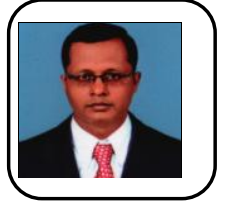

Dr. PL. Meyyappan has completed his graduation and post-graduation from Bharathiyar University and Karunya University respectively. He completed his $\mathrm{PhD}$ from Kalasalingam University. He has 13 years of teaching experience. He has completed 2 sponsored research projects from TNSCST and published more than 25 papers in peer reviewed journals and conferences. He is a life member in ISTE, IEI, IGS, ISET, ISRS. He is serving as Editorial Board Member and Reviewer in various reputed Journals.

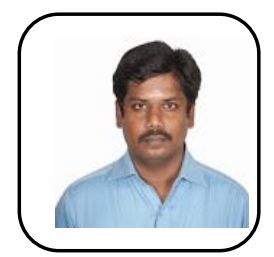

Dr M.Shanmugasundaram: He had completed his B.E degree in Civil Engineering from RCET Madurai, M.E in Structural Engineering, TCE Madurai. He completed his Ph.D in 2014 under the esteemed guidance of Dr. K.Sudalaimani, Professor, TCE, Madurai. He has 30+ international research publications to his credits. He had filed three patents. He has 3 years of industrial experience and 10 years of teaching experience. His recent research interests include, sustainable materials and polymer concrete.

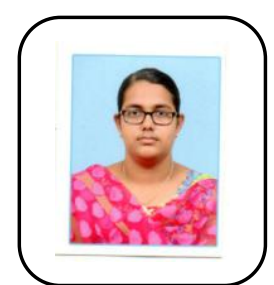

Ms.A.Ragasree completed her Bachelor of Engineering degree in Civil Engineering from Anna University, Chennai, Tamil Nadu, India in 2017. She is currently pursuing her Master of Technology in Structural Engineering from Kalasalingam Academy of Research and Education, Krishnan Koil, Tamil Nadu, India. 